\title{
Paris asks more of academics
}

\section{Protests over productivity demands}

The French university system is about to be taken by the scruff of the neck and given a good shake, just as it was in the student revolution of 1968 . The difference is that this time the government will be doing the shaking, and the objective is not so much student democracy as economic relevance.

To some left-wing university lecturers, the plans of education minister Alain Savary, outlined last week to the council of ministers and to university presidents, have been something of a rude awakening. Savary wants more students, more work from the university staff, and courses more closely linked to the jobs students might take in the outside world; and all this by October 1984 and with no real increase in university budgets. It is being said that only a socialist government could dare to be so firm. Giscard d'Estaing's minister Alice Saunier-Sëité was hounded for little more.

Savary's weapon is to be a new law for higher education, which will be put before the national assembly in the spring of 1983 . This will be the first reorganization of the university system since Edgar Faure's law of 1968 , which regrouped the previously autonomous "facilities" into multidisciplinary universities, gave students some constitutional power, and paved the way for the foundation of many new - and often very small - universities throughout France. Faure's law was said to be little more than a pacification of the rebels: it was thought out too hastily to last.

Savary's law, then, will tidy up the Faure reform, unlike Saunier-Sëité's plans, which were more to reject the reform altogether. Savary wishes to retain open entry to the first year, and indeed to increase the number of students by attracting more from the working class. He wants the first two years to be broadly orientated towards a profession, and the last year clearly so. He wants university staff to teach for longer hours, pay greater attention to their students and play a greater part in community life; and he wants better links between the universities, the independent university institutes of technology (which give a strictly professional training) and the prestigious grandes écoles (which produce top engineers, managers and the higher echelons of the civil service). He will also make it easier for universities to make profitable links with industry, in an attempt to encourage innovation, as the minister of research and industry tried to do for the research councils. Thus the whole tendency is to

open the universities to the economy.

So far, university staff have responded most strongly to the proposals for more students and more work. There are already so many students in the first year that most have to be turned away at the first selection - which comes for entry to the second year. The students who come and go in the first year are called the "ghost students". Does Savary want to create more ghosts, they ask? As for more work, the staff claim they are already overworked.

At the ministry, however, the universities are seen somewhat differently - as wastrels and spendthrifts. Already the director for higher education and research at the ministry, M. Jean-Jacques Payan, recently arrived from the directorgeneralship of the Centre National de la Recherche Scientifique, has addressed a letter to the universities ordering an extension of the university year from 25 weeks to 32 , and proposing a reduction (by 20-25 per cent) in the number of hours of part-time teaching to be allowed next year. This will increase the teaching load for fulltime staff without increasing pay. For some lecturers who are required to teach only

\section{Swedish crisis: keeping tryst}

Sweden's Social Democratic Party was returned to power last month with an election platform that included a major commitment to science, higher education and technical research. The first actions of the new government, however, were to devalue the krona and to announce the guidelines of a new "crisis programme" to combat inflation and boost public spending on social welfare (particularly housing and full employment). The programme, embodied in a bill to go before Parliament at the beginning of November, envisages a substantial drop in the standard of living. It should not, however, necessarily curtail the election platform on science and technology because many of the targets then urged by the Social Democrats have been reiterated by the crisis programme.

Both promise and programme urge the need for better use of the country's mineral and timber resources especially on energy. Indeed, according to the new Finance Minister, Mr Kjell-Olof Feldt, the crisis programme was largely necessary because Swedish industry is too energy-intensive and has been badly hit since oil prices rocketed in the 1970s. Thermal pumps, solar heating and hydroelectric power all featured prominently in the Social Democratic platform. The restructuring of the country's energy resources is particularly urgent, because, as a result of a national referendum, Sweden is committed to phasing out nuclear power within twentyfive years. three hours a week this may hardly be burdensome; but for others who already teach far more than their statutory requirement it will lead to resentment. Savary's problem may be to distinguish between those parts of the universities that really require reform (often non-scientific) and those that are already doing a good job (often scientific).

However, Savary is concerned with the broad mass of higher education in his law, not science itself. So there has been no mention in his statements of plans to alter the French higher degree system of a troisieme cycle ( 2 years postgraduate work and a thesis) and the thèse d'état (somewhat beyond a PhD and presented at the age of 30 or so). The omission does not indicate that the plans have been dropped, however. Chevènement introduced reform of this system - essentially to an America-style PhD - in his law for research, and Savary supported the innovation in the National Assembly. Jean-Jacques Payan also supports it, and so it is still expected to find its way into the Savary law next spring.

Robert Walgate

Similarly, although the tax concessions granted by the previous government to stimulate private investment in industry are to go, the crisis programme, according to $\mathrm{Mr}$ Feldt, would permit continued expansion in fields of investment likely to promote the future competitiveness of industry. This accords with the election platform which urged the establishment of a state structural development fund to help investment projects that would otherwise be difficult to finance. Election proposals for greater state participation in industrial research, the introduction of new scholarships for inventors and increased research grants to colleges of technology all fit in with the "crisis" investment strategy.

The reduction of unemployment is a major aim of the crisis programme. To some extent, young Swedes have tried to escape the dole queue by enrolling in higher education. University officials report a record number of applications this year, in many cases clearly motivated by the fact that one prefers to say one is a student rather than that one is unemployed. Moreover, the Swedish educational system is particularly convenient for such enrolments. Tuition is free in all Swedish universities and (in spite of cuts by the previous administration), there is a fairly extensive programme of financial aid in the form of a small non-returnable grant plus an interestfree loan (but with the principal pegged to inflation) repayable from one's future earnings, over up to 20 years. Moreover, the "democratization" of Swedish univer- 